\title{
about our members
}

Jill F. Hasling of the Weather Research Center, Houston, Texas, and a CCM, presented a Career Exploration Workshop entitled "Do You Sometimes Wake Up in a Fog? Let the Meteorologist Tell You Why." This workshop was presented at a conference for girls in grades 6-8 called Expanding Your Horizons in Math and Science, sponsored by the American Association of Univer-

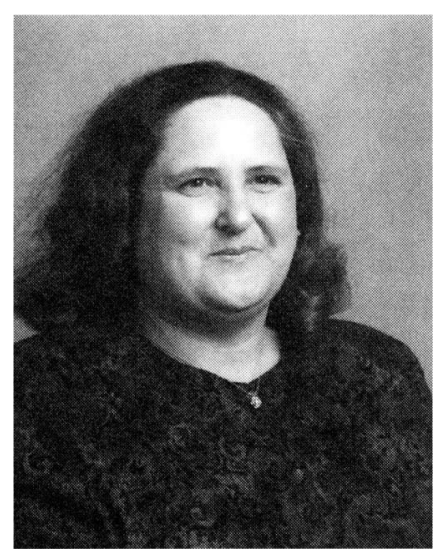

Jill F. Hasling sity Women. The conference goals were to make girls aware of career opportunities in math- and science-related fields, to provide girls an opportunity to become acquainted with female role models in math and science careers, to meet the needs of minority girls by providing conference information and role models of all ethnic backgrounds. The hit of the workshop was computerized weather educational games.

Hasling also participates in the Weather Research Center's weather day camp held each summer. The camp targets students aged 9-14 and teaches them weather basics, how to read instruments, and how to make observations.

Coastal Environmental Systems, Seattle, Washington, recently released, integrated, and expanded three of its products. The company released the WEATHERPAK ${ }^{\circledR}-2000$, a technologically advanced, integrated weather station designed for use in hostile environments on land or water. It uses a 32-bit processor that allows unlimited flexibility in programming $(C$ language), up to 18-bit $\mathrm{A} / \mathrm{D}$ resolution, $1 \mathrm{MB}$ data storage, and unparalleled speed and accuracy.

A new Type II, Series 2 PCMCIA card slot has been integrated into the Coastal Environmental Systems' ZENO ${ }^{\circledR}-3200$ datalogger. This expands the ZENO memory from 1 to $10 \mathrm{MB}$. The system works over the entire temperature range of ZENO, $-40^{\circ} \mathrm{C}$ to $70^{\circ} \mathrm{C}$, and consumes little power. The cards (2, 5, and 10 megabyte versions) can be removed to bring the data to the office or can be configured to store data at the site. The PCMCIA electronics fits into the existing ZENO housing.
Coastal Environmental Systems' Meteorological Tower System designs now reach $500 \mathrm{ft}$. Sensor signals are digitized at the sensor, which eliminates the possibility of electrical, magnetic, and radio noise. Individual offsets for each level are available in the ZENO ${ }^{\circledR}-3200$ software to factor out the Ekman Spiral effect on the wind direction (due to the Coriolis effect). If a wireless tower is desired, an optional spread spectrum radio communication link between the base electronics and each level is available.

Coastal Environmental Systems, a division of the Coastal Climate Company, is a manufacturer of meteorological monitoring systems.

Glenn E. Stout, executive director of the University of Illinois Urbana-Champaign (UIUC)-based International Water Resources Association (IWRA), was elected president of the organization for the term January 1995 through December 1997. The IWRA is headquartered at the UIUC Institute for Environmental Studies. Stout has also been appointed as a member of the nomination committee for this year's Stockholm Water Prize. This prize, which includes a cash amount of $\$ 200,000$, is the highest international award given for water-related research.

As IWRA president, Stout organized the International Conference on Water Resources Management in Arid Countries, held in Muscat, in the Sultanate of Oman, in March. He will also give the keynote address at the International Weather Radar Conference in São Paulo, Brazil, in August. He has been a member of the IWRA since 1973 and its executive director since 1984.

In all, Stout has more than 50 years of experience in research related to water and the atmospheric sciences. He headed the Water Resources Center at the Institute for Environmental Studies for more than 20 years until he retired in May 1994. He continues to serve the center as director emeritus. From 1980 to 1994, Stout continuously represented the academic community in Illinois on the Governor's Water Plan Task Force.

Dennis R. Lunderville has joined TRC Environmental Corporation, Lowell, Massachusetts, as director of Northeast Air Programs. He brings more than 23 years of experience to TRC, including experience as director of Air Resources for the Department of Environmental Services of the state of New Hampshire, where he was responsible for New Hampshire's implementation of the Clean Air Act Amendments of 1990. 
Supported by more than 60 air professionals in TRC's northeast offices, Lunderville will provide assistance to industrial clients in the region on air quality issues such as State Air Programs, Clean Air Act Title V Federal Operating Permits, and Title III Air Toxics Regulations.

Twenty-three years after his retirement from the military, Wayne E. McCollom retired on 1 April 1995 from his civilian career in meteorology. He spent the past 14 years in the Department of Defense civilian workforce, begin-
Wayne E. McCollom

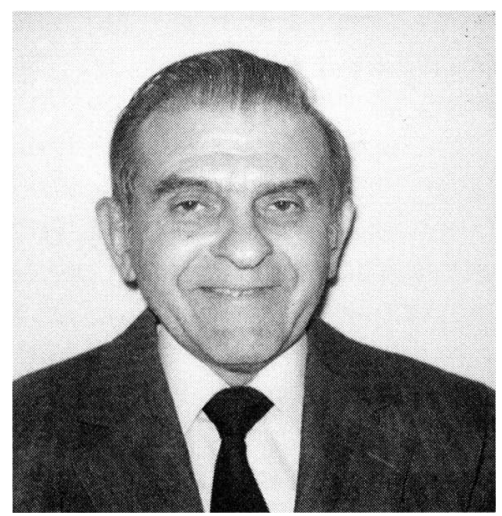
ning work on 15 December 1980 as a resource person in the U.S. Air Force Environmental Technical Application Center's Air Weather Service Technical Library. In this capacity, he was one of the first contacted to determine what research studies had already been completed on a new application of meteorology. The challenge was to be aware of or to be able to find new information quickly.

McCollom enlisted in the air force on 21 March 1952 as an airman basic. In his 20 years of active duty, McCollom moved 18 times. While at High Wycombe Weather Central, one of his many assignments, he was in charge of maintaining quality control. His colleagues were plotting numbers on charts and then drawing the lines and frontal positions. He retired as a major on 1 April 1972 while stationed at MacDill Air Force Base near Tampa, Florida.

After his military retirement, McCollom secured his Missouri Vocational Agriculture Teaching Certificate that he had earned before he joined the air force. His first job was as a part-time teacher in two public junior high schools in Columbia, Missouri. McCollom received a master of science degree in atmospheric science from the University of Missouri at Columbia on 30 July 1976. After graduation, he worked for the University of Missouri Atmospheric Science Department. He assisted graduate student research and helped beginning students find employment within the Atmospheric Science Department.
McCollom has been active in several local chapters of the AMS. While president of the West Coast Florida Chapter in 1970-1971, with the strong support of many local businesses, the chapter displayed its appreciation of active and retired weather personnel with a centennial celebration. He, with help from fellow chapter officers, was able to renew the vitality of the Greater St. Louis Chapter in 1992-1994.

\section{Dennis R. Stebbins}

of Honolulu, Hawaii, was appointed to serve on the National Society of Environmental Consultants' (NSEC) six member national advisory board. Stebbins was installed to the board during the society's Third Annual National Real Estate Environmental Conference, held in Las Vegas, Nevada, in February 1995.

As a member of the

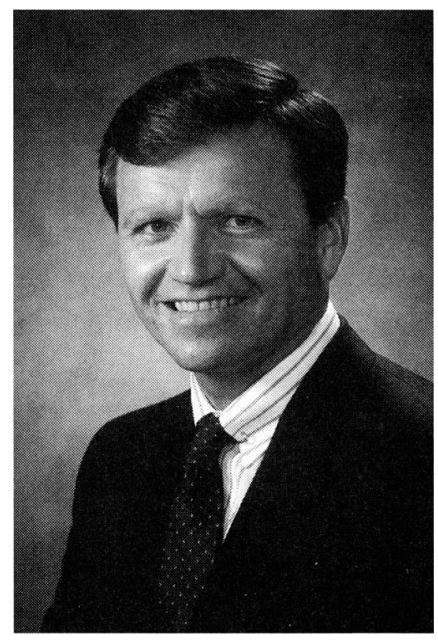

Dennis R. Stebbins NSEC advisory board,

Stebbins will serve to provide the society with professional advice and counsel regarding significant national and international environmental laws, regulations, and other concerns affecting the real estate, appraisal, and financial industries within the United States. He will also assist in providing direction regarding the society's various environmental consultant designation requirements, education, and training programs and member services.

Stebbins is president and chief executive officer of the Hawaii-based firm of Stebbins International LTD, an environmental management and educational consultancy. In addition, Stebbins serves as a special advisor and registered contract consultant for both the United Nations Environmental Programme and the United Nations Development Programme. Further, he is the founder and executive director of the organization called FERST (Foundation of Earth Resources, Sciences, and Technologies), a U.S. nonprofit organization focused toward providing environmental educational opportunites to people in developing nations. Stebbins, a member of AMS, is a retired naval officer who specialized in environmental science, meteorology, and physical oceanography. 